\title{
REDD+ and Green Growth : Synergies or discord in Vietnam and Indonesia
}

\section{Pham, Thuy Thu}

2017-08-01

Pham , T T, Moeliono , M , Brockhaus, M , Le , D N \& Katila , P 2017 , ' REDD+ and Green Growth : Synergies or discord in Vietnam and Indonesia ', International Forestry Review, vol. 19 , no. S1 , pp. 56-68 . https://doi.org/10.1505/146554817822407385

http://hdl.handle.net/10138/231463

https://doi.org/10.1505/146554817822407385

cc_by

publishedVersion

Downloaded from Helda, University of Helsinki institutional repository.

This is an electronic reprint of the original article.

This reprint may differ from the original in pagination and typographic detail.

Please cite the original version. 


\title{
REDD+ and Green Growth: synergies or discord in Vietnam and Indonesia
}

\author{
T.T. PHAM ${ }^{a}$, M. MOELIONO ${ }^{b}$, M. BROCKHAUS ${ }^{b, c}, N^{2}$.D. LE ${ }^{a}$ and P. KATILA ${ }^{d}$ \\ ${ }^{a}$ Center for International Forestry Research (CIFOR), No. 17A, Nguyen Khang Street, Cau Giay District, Hanoi 10000, Vietnam \\ ${ }^{b}$ CIFOR, Jalan CIFOR, Situ Gede, Sindang Barang, Bogor (Barat) 16115, Indonesia \\ ${ }^{c}$ University of Helsinki, P.O.Box 27, Latokartanonkaari 7, FIN-00014 University of Helsinki, Finland \\ ${ }^{d}$ Natural Resources Institute Finland (Luke), PO Box 18 (Jokiniemenkuja 1), FI-01301 Vantaa, Helsinki, Finland
}

Email: t.pham@cgiar.org, moeliono@cgiar.org,m.brockhaus@cgiar.org,dzunglengoc@gmail.com,pia.katila@luke.fi

\begin{abstract}
SUMMARY
Green Growth (GG) has emerged as a global narrative, replacing to some extent and integrating earlier sustainable development narratives, while Reducing Emissions through avoiding Deforestation and forest Degradation (REDD+) has developed as major item in climate change negotiations. GG and REDD+ are both considered important strategies and are often seen as synergistic in achieving major changes in economic, regulatory and governance frameworks. Of concern, however, is that GG is sometimes seen as greenwashing of economic activities (which could include forest conversion to other land uses) by an oversimplified presentation of win-win solutions without challenging the actual root causes of unsustainable growth. How GG and REDD+ can contribute to transformational change in policy and practice depends on the relationship between these narratives, especially whether their adoption in national level policies manifests synergies or discord. In this paper, we will answer this question through analysing: (1) how the two narratives have unfolded in Vietnam and Indonesia and to what extent REDD+ and GG rhetoric include concrete policy objectives; (2) what issues policy actors perceive as challenges for their implementation. A comparative, mixed methods approach was employed to analyze how REDD+ and GG are framed in national policy documents. This analysis was supported by data from interviews with policy actors in both countries in two points of time, 2011/12 and 2015/16. The findings highlight the challenges for implementation of both REDD+ and GG as individual policy programmes, and the dilution of the REDD+ agenda and decision makers' confusion about a GG strategy when these narratives are joined and translated by decision makers. Actors still perceive development and environmental objectives as a zero-sum struggle, favouring a development narrative that might lead to neither REDD+ nor green policy action. We conclude that REDD+ and GG can go hand in hand, if there is action to tackle deforestation and degradation.
\end{abstract}

Keywords: Vietnam, Indonesia, Green Growth, green economy, REDD+

\section{La REDD+ et la Croissance Verte: synérgie ou discorde au Vietnam et en Indonésie}

\section{T.T. PHAM, M. MOELIONO, M. BROCKHAUS, N.D. LE et P. KATILA}

La Croissance Verte ou 'Green Growth' (GG) émerge dorénavant comme un narratif global, remplaçant, et d'une certaine mesure intégrant des narratifs plus anciens de développement durable, alors que la Réduction de émissions en évitant la déforestation et la dégradation forestière (REDD+) est devenue un article majeur dans les négotiations de changement climatique. La GG et la REDD+ sont considérées toutes deux comme des stratégies importantes et sont souvent perçues comme étant synérgiques dans leur succès à opérer des changements majeurs dans les cadres économique, régulatoire et de gestion. Cependant, la GG est parfois percue comme un vague voile vert tiré sur les activités économiques (lesquelles pourraient inclure la conversion de la forêt à d'autres utilisations de la terre), du fait d'une présentation trop simplifiée de solutions tous avantages, sans faire face aux réelles cause profondes d'une croissance non durable. Le potentiel que la GG et la REDD+ récellent pour contribuer à une profonde transformation de la politique et de la pratique dépend de la relation entre ces narratifs, particulièrement si leur adoption dans les politiques au niveau national manifeste soit synérgie; soit discorde. Nous allons répondre à cette question dans ce papier, en analysant: (1) comment les deux narratifs se sont épanouis au Vietnam et en Indonésie, et à quel degré les rhétoriques GG et REDD+ incluent des objectifs politiques concrets; (2) quelles sont les questions que les acteurs de politique considèrent comme rendant leur mise en pratique ardue. Une approche comparative à méthode mixte a été employée pour analyser combien la REDD+ et la GG sont prises en compte dans les documents de politique nationale. Cette analyse est soutenue par des données résultant d'interviews avec des acteurs politiques dans les deux pays pendant deux périodes: 2011/12 et 2015/16. Les résultats mettent en lumière les défis rencontrés par la GG et la REDD+ dans leur application en programme de politique individuelle, ainsi que la dilution de l'agenda de la REDD+ et la confusion des preneurs de décision quant à une stratégie de la GG, quand ces narratifs sont joints et interprétés par les preneurs de décision. Les acteurs perçoivent encore le développement et les objectifs environnementaux comme une bataille sans résultat, favorisant par conséquent un narratif de développement qui pourrait conduire à une absence d'action de la REDD+ ou d'une politique verte. Nous concluons que la REDD+ et la GG peuvent progresser de concert si action est prise de faire face à la dégradation et à la déforestation. 


\title{
REDD+ y el Crecimiento Verde: sinergias o discordia en Vietnam e Indonesia
}

\author{
T.T. PHAM, M. MOELIONO, M. BROCKHAUS, N.D. LE y P. KATILA
}

El Crecimiento Verde o 'Green Growth' (GG) ha surgido como una narrativa global que reemplaza en cierta medida, e integra, las narrativas anteriores sobre desarrollo sostenible, en paralelo al desarrollo de la Reducción de las Emisiones de la Deforestación y la Degradación de Bosques (REDD+) como uno de los temas principales en las negociaciones sobre cambio climático. GG y REDD+ son consideradas como estrategias importantes que a menudo son vistas como sinérgicas para el logro de cambios importantes en los marcos económicos, regulatorios y de gobernanza. Sin embargo, es preocupante que a veces se considere el GG como un lavado verde de las actividades económicas (que podrían incluir la conversión de bosques para otros usos del suelo) mediante una presentación simplista de soluciones ganadoras sin cuestionar las verdaderas causas del crecimiento no sostenible. La manera en que el GG y REDD+ pueden contribuir a un cambio transformacional en la política y la práctica depende de la relación entre estas narrativas, especialmente si su adopción en políticas a nivel nacional genera sinergias o discordia. En este artículo se responde a esta cuestión mediante el análisis de: (1) cómo se desarrollaron las dos narrativas en Vietnam e Indonesia, y en qué medida la retórica sobre REDD+ y GG incluye objetivos políticos concretos; (2) las cuestiones que los actores políticos perciben como desafíos para su implementación. Para analizar cómo se enmarcan REDD+ y el GG en los documentos de políticas nacionales se utilizó un enfoque comparativo de métodos mixtos. El análisis se apoyó en datos de entrevistas a actores políticos en ambos países en dos momentos: 2011/12 y 2015/16. Los resultados ponen de relieve tanto los desafíos para la implementación de REDD+ y del GG como programas políticos individuales, como el debilitamiento de la agenda de REDD+ y la confusión de quienes toman las decisiones sobre una estrategia de GG cuando estas narrativas van unidas y son traducidas por quienes toman las decisiones. Los actores todavía perciben los objetivos de desarrollo y medioambientales como un conflicto de 'suma cero', que favorece una narrativa de desarrollo que puede que no conduzca ni a REDD+ ni a acciones de políticas verdes. Se concluye que REDD+ y el GG pueden avanzar a la par, a condición de que haya acciones para combatir la deforestación y la degradación.

\section{INTRODUCTION}

Green Growth (GG) has emerged as global narrative, replacing and integrating earlier sustainable development narratives. Many scholars have pointed out that GG is not new but developed from the 'sustainable development' narrative that emerged from the 1987 Brundtland Report and 1992 Rio Earth Summit (Jacob et al. 2013) where issues of limits to growth, climate change, environmental impacts and dwindling natural resources took center stage. There are also various definitions of GG, as discussed in the next section, but in general it can be seen as a strategy for building a green economy (GE) in the context of sustainable development and poverty reduction. While there is no internationally agreed definition of GE, an often-cited definition is that of UNEP (2011), which defines a green economy as "one that results in improved human well-being and social equity, while significantly reducing environmental risks and ecological scarcities". Globally GG gained momentum during the global financial crisis and became a mainstream development approach with commitments from the World Bank, Organisation for Economic Co-operation and Development (OECD) and the United Nations Environment Programme (UNEP). As broader policy objectives, they have also become dominant global narratives and have been translated to varying extents in different national policy arenas. For example, in Vietnam, GG is adopted as national strategy, and in Indonesia it is currently being integrated in national planning documents.

Reducing Emissions from Deforestation and Degradation (REDD+) is often considered to be an important component of a GG in tropical countries due to its contribution to a country's mitigation potential and as a particular form of 'environmental governance' (Anderson et al. 2015). REDD+ is expected to promote economic growth and reduce poverty as part of a GG policies and to contribute to a 'virtuous cycle' of investments in natural and human capitals that are catalysts for green development (UN-REDD 2014, UNEP 2014). These stances have been taken by both Vietnam and Indonesia.

However, what are the implications for REDD+ when merging REDD+ and GG narratives ? Could linking REDD+ and $\mathrm{GG}$ as strategies towards a green economy lead to a more effective implementation of both, as argued for example by organisations such as UNEP (2014)? Or, when taking into account the political economy of deforestation and forest degradation and its underlying causes and agents, would linking GG and REDD+ simply lead to an inflated green rhetoric without implementation, because powerful economic interests benefit from the status quo and have little interest in major changes?

One the one hand, REDD+ is built on a results-based payment idea (i.e. effective payments for performance require measurable carbon and non-carbon outcomes), but in most countries measurable results are not yet a reality (KorhonenKurki et al. 2014, Brockhaus et al. 2015). On the other hand, GG remains a rather vague concept and it has been heavily criticized for often unclear or even distorted meanings, and a rhetoric that presents current market structures, growth models and consumption patterns as a solution rather than questions their role as a possible root cause of current environmental problems (Bluehdorn 2011).

To investigate the possible implications for an effective policy implementation of both GG and REDD+ we investigate (1) how the GG and REDD+ narratives have unfolded in Vietnam and Indonesia and (2) what concrete policy objectives are included in these narratives, (2) what issues policy actors perceive as challenges for the implementation of GG and REDD+. We then finally question if these concurrent 
narratives will lead to higher ambition to reconcile environmental and economic goals, or just to higher ambiguity, and to a loss of the few more clearly defined objectives and their operationalization in REDD+. Vietnam and Indonesia are selected as they are the pioneer countries in both REDD+ and GG in Southeast Asia.

Our paper focuses on comparing how REDD+ and GG are framed in various policy documents and how sustainable development is framed within REDD+ policy documents, and in conventional agriculture and forestry based development policy documents. The paper then identifies potential mismatches. In addition, policy document review, stakeholders' statements and perceptions of GG, REDD+ and sustainable development are analysed. Following this, the paper identifies potential conflicting objectives or ways of implementation and suggests ways to overcome them.

The paper is structured in 7 sections. The concepts of REDD+ and GG are presented in the next section followed by the description of the methods used. The results of the policy document analysis and the findings from the analysis of actors's understandings and position statements with regard to challenges for implementing REDD+ and a green economy are then presented in sections 4 and 5. A discussion of the findings and a conclusion are presented in sections 6 and 7.

\section{REDD+ AND GG: CONCEPTS AND DEFINITIONS}

\section{Green growth}

Sustainable development was a political strategy for global environmental and resource management, ecological modernization and an attempt to reconcile environmental problems with development (Brand 2012, Jacob et al. 2013). GG takes it a step further, claiming that protecting the environment can yield better growth. The concept of sustainable development emerged from the environmental movement, where the ideological argument about the 'limits to growth' was widespread, while GG emerged from the more mainstream and pragmatic community of environmental economic policy makers (Jacob et al. 2013). Although the issue of growth is being debated, the concepts and models of growth remain within a traditional growth paradigm (Schulz and Bailey 2014) and the focus on economic growth gives GG much greater purchase on mainstream economic policy making (OECD 2012, World Bank 2012). Indeed, GG narratives have no uniform interpretation (Table 1).

What these definitions have in common is the underlying concern that the necessary level of environmental protection is not met through the 'business-as-usual' patterns of growth (Jacob et al. 2013). GG is thus an attempt to merge the pillars of sustainable development into a single policy planning process that aims to provide enabling economies to maintain growth in the long-term (GGGI 2013, Samans 2013). However, different discourse on GG adopted throughout the world reveals an economisation and polarisation of discourses, the persisting weak interpretation of sustainable development, and a tension between the fixing or shifting of dominant socioeconomic paradigms that underpin its conceptualisation (Bina 2013). Kenis and Lievens (2015) also asserted that GG discourse is an attempt to re-invent capitalism.

Like sustainable development, GG might be difficult to put into practice. The rhetoric without any policy action may lead to what Bluehdorn (2011) calls "the politics of unsustainability", where the interest of entrenched political and power positions become portrayed as the solution rather than being

TABLE 1 Various interpretations of $G G$ narratives

\begin{tabular}{|c|c|}
\hline GG narratives & Authors \\
\hline $\begin{array}{l}\text { GG aims to include environmental factors into economic decision-making and policies by introducing: } \\
\text { resource efficiency, transforming energy systems, valuing natural capital in the economic calculus, and } \\
\text { pricing of environmental externalities }\end{array}$ & $\begin{array}{l}\text { Jouvet and De Perthuis } \\
2013 \text { in Scott et al. } \\
2013\end{array}$ \\
\hline GG is a way to address GHG emissions and environmental degradation that growth has brought & Jupesta et al. 2011 \\
\hline $\begin{array}{l}\text { Growth that emphasizes environmentally sustainable economic progress to foster low-carbon, socially } \\
\text { inclusive development }\end{array}$ & UNESCAP \\
\hline $\begin{array}{l}\text { Fostering economic growth and development, while ensuring that natural assets continue to provide the } \\
\text { resources and environmental services on which our well-being relies. }\end{array}$ & OECD \\
\hline $\begin{array}{l}\text { Growth that is efficient in its use of natural resources, clean i.e. it minimizes pollution and environmental } \\
\text { impacts, and resilient i.e. it accounts for natural hazards and the role of environmental management and } \\
\text { natural capital in preventing physical disasters }\end{array}$ & World Bank \\
\hline $\begin{array}{l}\text { GG is a revolutionary development paradigm that sustains economic growth while ensuring climatic and } \\
\text { environmental sustainability. It focuses on addressing the root causes of these challenges while ensuring } \\
\text { the creation of the necessary channels for resource distribution and access to basic commodities for the } \\
\text { impoverishe }\end{array}$ & GGGI \\
\hline $\begin{array}{l}\text { GG is: 'a regional strategy for achieving sustainable development. . GG advocates growth in GDP that } \\
\text { maintains or restores environmental quality and ecological integrity, while meeting the needs of all } \\
\text { people with the lowest possible environmental impacts. It is a strategy that seeks to maximise economic } \\
\text { output while minimising the ecological burdens...' }\end{array}$ & UN \\
\hline
\end{tabular}


considered the root cause of environmental policy problems - resulting in no shifts in the economic, regulatory or social frameworks. Yet, or maybe because of this, the narratives of GG seem to be adopted globally and are promoted as the new answer to global development. For developing countries, the main aim is to foster economic growth (UN and ADB 2012). Natural assets are to be 'used' sustainably and continue to provide the resources and environmental services upon which growth and well-being rely (OECD 2012). At the same time, this acceptance of 'growth' as a taken-for-granted paradigm might be one of the biggest obstacles towards 'green' development (Schulz and Bailey 2014).

\section{REDD+}

REDD+ was originally conceived as a straightforward programme to finance the protection of tropical forests through the sale of carbon offsets or from donor funding. What started as a simple concept with the main objective of reducing emissions globally to mitigate climate change has become a complex scheme expected to fulfill multiple expectations to a range of stakeholders, from local farmers to global climate negotiators (Angelsen and McNeil 2012). After decades of evolution and years of difficult negotiations, REDD+ is formally recognized in the United Nations Climate Change Framework in Paragraph 2:

"Parties are encouraged to take action to implement and support, including through results-based payments, the existing framework as set out in related guidance and decisions already agreed under the Convention for: policy approaches and positive incentives for activities relating to reducing emissions from deforestation and forest degradation, and the role of conservation, sustainable management of forests and enhancement of forest carbon stocks in developing countries; and alternative policy approaches, such as joint mitigation and adaptation approaches for the integral and sustainable management of forests, while reaffirming the importance of incentivizing, as appropriate, non-carbon benefits associated with such approaches."

In line with the various definitions that emphasize climate issues, REDD+ has been positioned as a way of achieving GG. REDD+ implementation requires a mix of policy instruments, which must be informed by sound planning and active support from different actor groups (Brockhaus et al. 2014, UNEP 2014, Di Gregorio et al. 2015). The same REDD+ actors, institutions, networks and institutions will be engaged in a potential GG transition (Watson et al. 2013).

\section{METHODS}

Narrative policy analysis is used as the general framework for this study. Narratives are referred as "a way of structuring and communicating our understanding of the world" (Shannan et al. 2011). In the context of policy processes and policy development, narratives center on the diverse understandings of the issues at hand, their causes and possible solutions, and related implications and opportunities (Shannan et al. 2011). This relates narratives to the frames different stakeholders use to understand and explain the world, but also to promote a particular problem definition. Framing can be understood as a particular way of interpreting and representing the social and physical world. For political purposes, framing often presents facts in such a way that implicates a problem that needs a clear guide for action (Entman 1993).

A range of methods (literature, legal reviews, in-depth interviews, text analysis) was used to address the above research questions. First, a historical perspective and review how the GG narrative developed in Vietnam and Indonesia was applied. A review was also conducted on past and existing climate change related documents including Intended Nationally Determined Contributions (INDC), forest, REDD+, sustainable development, and GG policies, to see how the Government of Vietnam and Indonesia have interpreted, adopted and adapted a GG strategy, and how REDD+ was expected to play a role in support of this.

Interviews were then conducted with representatives of 52 organisations that are important to REDD+ in Vietnam and 63 in Indonesia during 2011-2015. The interviews sought to uncover the respondents' framing of REDD+ and GG by focusing on their understandings, opinions and views on REDD+ and GG, and what are seen as the opportunities and constraints for implementation of these strategies separately as well as jointly in both policy design and policy implementation. We also recognize two major limitations of our methods. First, our interviews can only capture a one-time snapshot while stakeholders' perceptions might be subjective and therefore change over time according to circumstance. Secondly, our interviewees, although assigned by their organisations as formal representatives and spokesmen, might not be directly involved in the development of REDD+ and GG strategy.

\section{REDD+ AND GREEN GROWTH IN VIETNAM AND INDONESIA: DEVELOPMENT OF A NARRATIVE}

In Southeast Asia, only Vietnam and Indonesia have launched dedicated national GG strategies (Jacob et al. 2013) and national REDD+ strategies (GoV 2012, GoI 2012, Figure 1). Subsequently, the two countries have adopted GG terminology in the policy discourse and as part of different policy documents, driven by a variety of different motivations such as export opportunities; the need to create fiscal revenues; concerns about climate change; and international climate policies and related funding opportunities (Jacob et al. 2013).

In both countries, reducing GHG emissions is an important component of the GG programmes. Both countries have included elements relevant to REDD+ as part of the GG strategies, including: a strong focus on 'restoring forest', increasing forest cover further $(47 \%)$ by 2020 , a focus on rehabilitating degraded lands and promoting market-based instruments (post-2020) (VNFOREST 2013, BAPPENAS 2015). The GG and REDD+ agendas, however, are linked in different ways in the two countries. 
FIGURE 1 Evolution of sustainable development, green growth and REDD+ in Vietnam and Indonesia

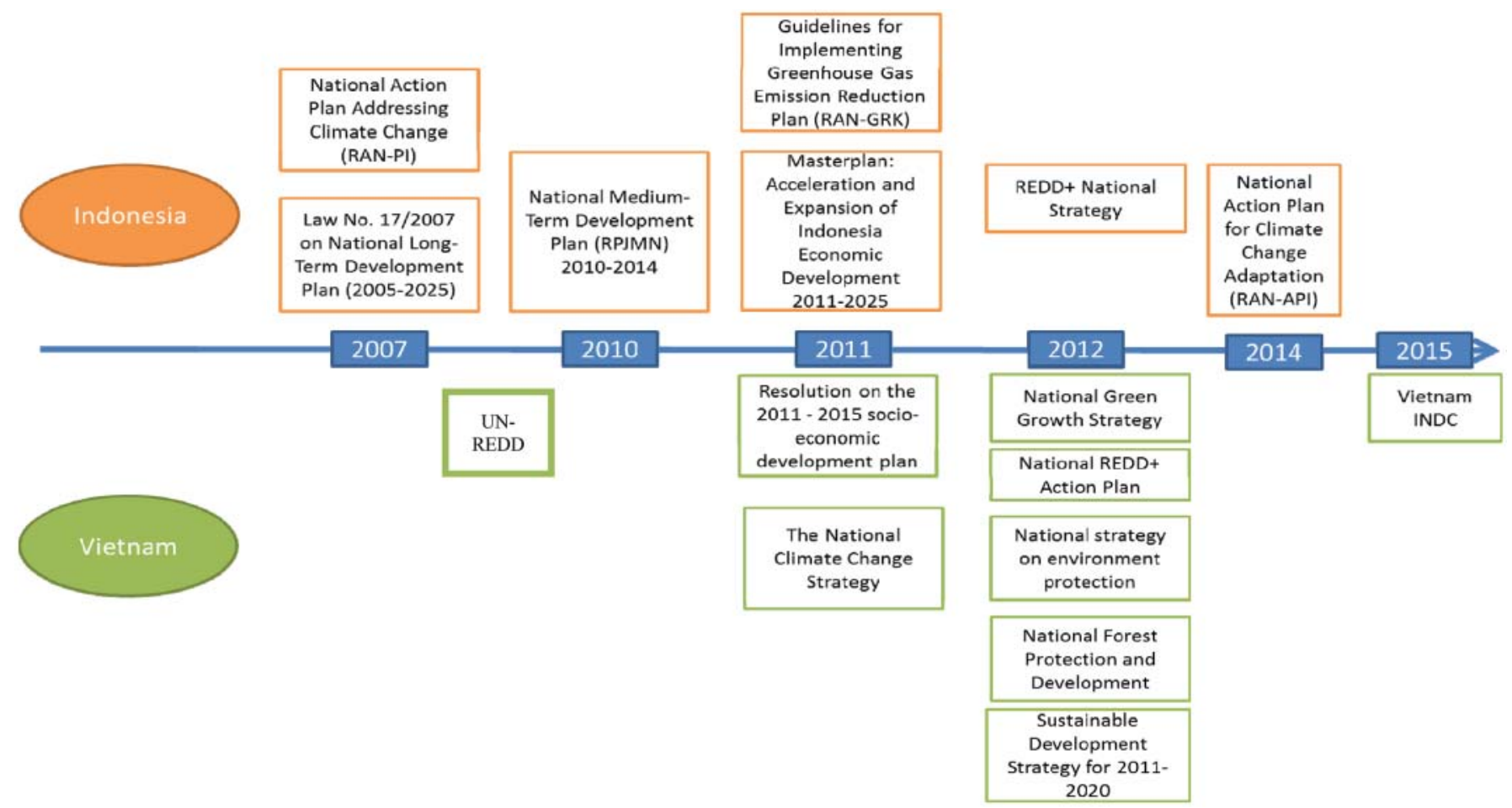

Apart from the potential of REDD+ to contribute to emission reduction targets in both countries, and in the case of Vietnam the formal integration of REDD+ in a national GG strategy, there are further connections between the two. In Indonesia, GG is promoted primarily by Ministry of National Development Planning supported by the Global Green Growth Institute (GGGI) of which the Government of Indonesia is a co-founder. In April, 2013, a Memorandum of Understanding with GGGI was signed to collaborate on the joint GoI-GGGI Green Growth Program (GGP). In the resulting framework the role of REDD+ in GG is explained as "to support the development of a funding mechanism that disburses REDD+ finance to catalyze GG'. Indeed, phase I of the Program (2013-2015) besides mainstreaming GG in development also focused on building local capacity for reducing GHG emissions from deforestation and forest degradation (REDD+) within a GG framework (GoI and GGGI 2013). In addition, as a number of different actors in both countries highlighted in recent interviews, REDD+ is seen as a key component to ensure the success of the GG strategy (Interview \#7, \#74 in Vietnam, 2015) as it promotes forest sector reform and sustainable forest management (Slunge et al. 2011). The following sections will provide a detailed analysis on how REDD+ and GG unfold in each country.

\section{Vietnam}

According to all interviewees, both REDD+ and GG emerged in Vietnam due to concern about the serious impact of climate change on agricultural production and the national economy. The latest INDC highlights the importance of both REDD+ and GG in reducing emission (Table 2). Key REDD+ and GG policies also emphasise the need for a close linkage between the two concepts. The National REDD+ program was approved in 2012 and was revised in 2016. REDD+ is currently managed by Ministry of Agriculture and Rural Development (MARD). The Vietnam Green Growth Strategy (VGGS) was also approved by the prime minister in 2012 and is managed by Ministry of Planning and Investment. VGGS shows strong government commitment in addressing the environmental and socioeconomic challenges (Interviews \# 36, \#20, \#16, 2015). The VGGS also addresses the process of economic restructuring towards more sustainable use of natural resources and with it the reduction of GHG emissions by $8 \%$ by 2030 compared to the business-as-usual scenario or up to $25 \%$ with international support (GoV 2015). In a GG strategy, forestry activities are also expected to contribute to a reduction of about 19 million tons CO2 from 2012-2020, and REDD+ is seen as a possible link to offset mechanisms and carbon taxes (VNFOREST 2013), as an element in the GG toolbox, and a link that provides access to funding. REDD+ is also seen as an important component of Vietnam's climate change mitigation efforts and is central to both the National Climate Change Strategy and Vietnam Green Growth Strategy (Table 2).

Policy makers interviewed also asserted that GG and REDD+ are portrayed as complementary policy tools and approaches to secure funding from both domestic and international actors for the implementation of national climate change adaptation and mitigation strategies. Political debates focus on how REDD+ can play a part in this road map. Interviews with government actors highlighted how uncertainty of 
TABLE 2 National REDD+ program and National Green Growth Strategy in Vietnam

\begin{tabular}{|c|c|c|c|}
\hline Policy document/Year & Lead agency & Objective/Viewpoints & Target actions \\
\hline $\begin{array}{l}\text { Vietnam National } \\
\text { Green Growth } \\
\text { Strategy/2012 }\end{array}$ & $\begin{array}{l}\text { Ministry of } \\
\text { Planning and } \\
\text { Investment }\end{array}$ & $\begin{array}{l}\text { Green growth, as a means to achieve } \\
\text { a low carbon economy and to enrich } \\
\text { natural capital, will become the } \\
\text { principal direction in sustainable } \\
\text { economic development; reduction of } \\
\text { greenhouse gas emissions and } \\
\text { increased capability to absorb } \\
\text { greenhouse gas are gradually } \\
\text { becoming compulsory and important } \\
\text { indicators in socio-economic } \\
\text { development }\end{array}$ & $\begin{array}{l}\text { Implement programs to reduce greenhouse gas } \\
\text { emissions through efforts in REDD+, } \\
\text { sustainable forest management in combination } \\
\text { with diversifying livelihoods of rural people }\end{array}$ \\
\hline $\begin{array}{l}\text { Vietnam National } \\
\text { REDD+ program/2012 }\end{array}$ & $\begin{array}{l}\text { Ministry of } \\
\text { Agriculture and } \\
\text { Rural } \\
\text { Development } \\
\text { (MARD) }\end{array}$ & $\begin{array}{l}\text { To reduce net GHG emissions, to } \\
\text { contribute to sustainable forest } \\
\text { management, biodiversity } \\
\text { conservation, and successful } \\
\text { implementation of the National } \\
\text { Strategy on Climate Change, poverty } \\
\text { alleviation and sustainable } \\
\text { development }\end{array}$ & $\begin{array}{l}\text { Integration of REDD+ implementation into the } \\
\text { National Program on Climate Change, the } \\
\text { Green Growth Strategy, the Forest Protection } \\
\text { and Development Plan 2011-2020, the wise } \\
\text { agricultural initiatives toward response on } \\
\text { climate change, the policies on payment for } \\
\text { forest environmental services (PFES), } \\
\text { agriculture-forestry extension service and } \\
\text { poverty reduction as well as other relevant } \\
\text { programs and projects to enhance its } \\
\text { effectiveness and sustainability }\end{array}$ \\
\hline Vietnam INDC/2015 & $\begin{array}{l}\text { Government } \\
\text { office }\end{array}$ & $\begin{array}{l}\text { Responding to climate change must } \\
\text { be associated with a transition } \\
\text { towards a low-carbon economy }\end{array}$ & $\begin{array}{l}\text { Integrate and effectively use domestic and } \\
\text { international resources for implementation of } \\
\text { programmes and projects related to forest } \\
\text { management and development, livelihoods and } \\
\text { biodiversity conservation such as REDD+, the } \\
\text { policy of payment for forest environmental } \\
\text { services (PFES) }\end{array}$ \\
\hline
\end{tabular}

Sources: GoV(2012); GoV (2015)

REDD+ global negotiations and markets has weakened the interest of government in REDD+. The government is now more interested in GG whereby REDD+ is a tool to obtain more funding to support national GG strategy. Yet, several donors have been skeptical about this political interest as "it remains unclear if the government really understands what is GG and what green entails or if it is simply a slogan to attract donor funding' (Interview \#18, 2015). At the same time, according to several interviewees representing donors and MARD leaders, having REDD+ as key component of GG ensures the success of GG strategy as it is unlikely that the energy sector can reduce its emissions while forestry emissions reduction is already seen as a pre-condition for success.

Despite of the political commitment and interest in joining REDD+ and GG, our analysis shows major challenges in both implementing each individual concept as well as combining them together.

First, a factor that was pointed out as a challenge for linking REDD+ to GG by the government interviewees is the different level of government ownership of these programmes. All interviewees claimed that the REDD+ program is donor driven, resulting in a lack of ownership from government and national stakeholders. In contrast, GG, although also in receipt of international support, according to most interviewees, is driven by government interest and ownership built upon its socio-economic development strategy. As a result, although GG and REDD+ are seen as complementary and interlinked, sectoral policies are still treating them as separate. For example, while GG is mainstreamed in numerous key environmental policies, they currently overlook REDD+ (Table 3). According to government interviewees, the exclusion of REDD+ in those strategies means a lack of political will and budget allocated to implementation of REDD+. Similarly, major forest policies such as the Forest Protection and Development Plan 2020 do not include GG but it is included in Vietnam INDC and Vietnam Green Growth Strategy.

Secondly, according to government interviewees GG is primarily developed within the country's Socio- economic Development Plan which refers to economic growth as one of the prime developmental objectives for Vietnam. In fact, the government also specified a development goal of increasing the economy's growth rate by $20 \%$ and reducing the poverty rate by $20 \%$ by 2020 (GoV 2012). All socioeconomic development strategies since the 1990s have targeted significant GDP growth. However, the second (2001-2010) and third 
TABLE 3 Integration of GG and REDD+ in environmental and development policies in Vietnam

\begin{tabular}{|c|c|c|c|c|}
\hline $\begin{array}{l}\text { Name of } \\
\text { document/Year }\end{array}$ & Lead institution & Objectives/viewpoint & $\begin{array}{l}\text { Reference } \\
\text { to REDD+ }\end{array}$ & $\begin{array}{c}\text { Reference } \\
\text { to GG }\end{array}$ \\
\hline $\begin{array}{l}\text { The National } \\
\text { Climate Change } \\
\text { Strategy/2012 }\end{array}$ & $\begin{array}{l}\text { Ministry of } \\
\text { Natural Resources } \\
\text { and Environment } \\
\text { (MONRE) }\end{array}$ & $\begin{array}{l}\text { Target: To turn low-carbon economy and green growth into } \\
\text { main orientations for sustainable development; lower } \\
\text { emission and higher absorption of greenhouse gases to } \\
\text { become compulsory indicators of socio-economic } \\
\text { development, and to increase competitiveness and strengthen } \\
\text { the national position, and carry out adaptation and mitigation } \\
\text { efforts in parallel. }\end{array}$ & None & Yes \\
\hline $\begin{array}{l}\text { National Strategy } \\
\text { on Environment } \\
\text { Protection to } \\
2020 \text { With } \\
\text { Visions to } \\
2030 / 2012\end{array}$ & MONRE & $\begin{array}{l}\text { Visions to 2030: To prevent and push back environment } \\
\text { pollution, resource deterioration and biodiversity degradation; } \\
\text { to improve quality of the habitat; to actively respond to } \\
\text { climate change; to create fundamental conditions for a green } \\
\text { economy, with low waste and low carbon, for country's } \\
\text { prosperity and sustainable development }\end{array}$ & None & Yes \\
\hline $\begin{array}{l}\text { National Forest } \\
\text { Protection and } \\
\text { Development } \\
\text { Plan/2012 }\end{array}$ & $\begin{array}{l}\text { Ministry of } \\
\text { Agriculture and } \\
\text { Rural } \\
\text { Development } \\
\text { (MARD) }\end{array}$ & None & $\begin{array}{l}\text { Brief } \\
\text { reference on } \\
\text { existing } \\
\text { program }\end{array}$ & None \\
\hline
\end{tabular}

(2011-2020) Socio-Economic Development Strategy (SEDS) framed economic growth in a context of establishing a socialist-orientated market economy and in laying the foundation for a modern, industrialized country by 2020 with sustainable development, environmental protection and economic growth. The SEDS was developed before approval of VGGS and therefore the term GG was not explicitly expressed in these documents. However, the earlier SEDS already emphasised that growth needs to be coupled with environmental sustainability. Therefore, according to the government agencies interviewed, SEDS is already aligned with GG. REDD+, however, is not referred to in those key economic development policies (Table 4).

Thirdly, according to Vietnam's INDC, the legal framework for integrating climate change issues into national Socio-Economic Development Plans is still limited and there is ineffective coordination between line ministries, sectors and provinces to address multi-sectoral and inter-regional issues. All interviewees claimed that GG is seen as the Ministry of Planning and Investment's (MPI) territory and REDD+ is MARD's territory with no interlinkages. At the macro level, the MPI coordinates and allocates the budget and prepares national sectoral plans and leads the design and implementation of GG. MPI also sees GG as a way to strengthen the country's image in the global policy arena and as a way to strengthen its political status. Ministry of Finance (MoFi) establishes financial norms related to any transactions. Technical ministries provide technical guidelines for each sector (e.g. MARD for REDD+, Ministry of Industry and Trade for energy) but are supervised by MPI and MoFi. However, all the stakeholders interviewed claimed that MPI and MoFi were not part of any REDD+ policy discussion. MARD, the civil society organization (CSOs) and NGOs have limited involvement in GG strategies development. Only $30 \%$ of total REDD+ policy actors participated in Green Growth policy decision making and only $20 \%$ of those actors showed high interest in Green Growth. Interestingly, interviewees from MARD who are responsible for REDD+ showed relatively low interest in GG. "GG is a pie of MPI that will not be shared with other ministries. We just submitted our sectoral proposal as part of GG but funding to our sector from GG will be very limited", an interviewee stated. Furthermore, while MPI and MoFI chose to exclude themselves in most REDD+ policy events, MARD interviewees have no influence over GG

TABLE 4 Economic Development Policies in Vietnam

\begin{tabular}{|c|c|c|c|}
\hline Name of document/Year & Lead institution & Reference to GG & Reference to REDD+ \\
\hline $\begin{array}{l}\text { Resolution on the } 2011-2015 \text { socio-economic development } \\
\text { plan/2011 }\end{array}$ & Government office & None & None \\
\hline Sustainable development strategy 2011-2020/2012 & Government office & None & None \\
\hline $\begin{array}{l}\text { Master plan on economic restructuring in association with } \\
\text { conversion of the growth model towards improving quality, } \\
\text { efficiency and competitiveness during the 2013-2020 period }\end{array}$ & None & None & None \\
\hline
\end{tabular}


outcomes (Pham et al. 2014). Similarly, 90\% of REDD+ actors also claimed that they only participated in consultative workshops on GG policy but were not be able to make any influence on GG outcomes. Furthermore, although there were many legal documents and policies that require integration of GG and REDD+ (Tables 2, 3), interviewed stakeholders did not elaborate these two concepts in practice.

\section{Indonesia}

'Sustainable development' has been a buzzword in Indonesia since the Conference in Rio in 1992 and has made its way into almost all development planning documents (Table 5). In 2004, the President, Susilo Bambang Yudhoyono, began to promote the need to address climate change through GG. During his government, in 2006, Indonesia adopted the energy mix policy aimed mainly at reducing oil consumption by partially shifting to renewable energy sources (Jupesta et al. 2011). After 2007, when Indonesia was host to the 13th COP of the UNFCCC, climate change became even more prominent in the national policy agenda (Jacob et al. 2013). In 2009, the President announced plans to reduce GHG emissions by $26 \%$ from business-as-usual, with a further $15 \%$ with adequate international support (Jupesta et al. 2011, BAPPENAS 2015).

TABLE 5 Government documents framing sustainable/green development in Indonesia

\begin{tabular}{lll}
\hline Name of document & & \multicolumn{1}{c}{ Description } \\
\hline $\begin{array}{l}\text { Long Term National Development Plan } \\
\text { (RPNJP) } 2005-2025 \text { formalized in Law }\end{array}$ & $\begin{array}{l}\text { Indonesia/ } \\
\text { Parliament/ }\end{array}$ & $\begin{array}{l}\text { Provides the basic framework and } \\
\text { direction for development in Indonesia to } \\
\text { be elaborated in four 5-year medium term } \\
\text { plans (RPJM). The framework applies }\end{array}$ \\
& & $\begin{array}{l}\text { concept built around sustainable } \\
\text { development based on three pillars: } \\
\text { competitiveness, inclusiveness and }\end{array}$ \\
& & sustainability.
\end{tabular}

\begin{tabular}{ll}
\hline National medium-term development & National Planning \\
plan (Rencana Pembangunan Jangka & Agency
\end{tabular}
Menengah Nasional, RPJM) 20152019
Third phase of the long term national plan identifying green economy as the foundation of the country's development programme, with emphasis on "inclusive and sustainable growth, increasing value added of natural resources with the sustainable approach, increasing quality of environment, disaster mitigation and tackling climate change".

Master plan: Acceleration and Expansion of Indonesia Economic Development 2011-2025 (MP3EI)

Coordinating
Ministry of
Economic Affairs

Economic Affairs
The MP3EI is intended to complement and become part of the RPJPN and RPJMN, to accelerate and disseminate development efforts more equitable throughout the nation using a not business-as-usual approach. It intends to integrate 3 elements: develop economic potential in 6 economic corridors; improve connectivity and strengthen human resources and technology

Master plan: Acceleration and Expansion of Poverty Reduction

A series of Ministerial Decrees since
Additional document providing guidance to reduce poverty

Reduce poverty from $12 \%$ to $4 \%$
By 2025 , per capita income of USD 14.250 - USD 15.500 with a total GDP of USD 4,0 $-4,5$ trillion. 2010 promoting renewable energy and energy conservation and Mineral Resources

Provides guidelines for investment and funding; incentives; energy pricing; human resource development; information dissemination; standardisation and certification; promotion of research and development; and institutionalisation of renewable energy.

Law 32/2009 Environmental Protection Parliament/ and Management
Ministry of

Environment and Forestry
This law seeks to ensure that development is underpinned with the principle of sustainably and environmentally sound development principles. 
The Indonesia Climate Change Sectoral Roadmap was drafted in 2009 and the National Action Plan (RAN-GRK) in 2011 (OECD 2014, Anderson et al. 2015). Subsequently, in June 2013, the Global Green Growth Institute (GGGI) launched a countrywide Green Growth Program, confirming and reinforcing the government's intention to stimulate lowcarbon investments (Anderson et al. 2015). By 2012, GG had become fully accepted as a development strategy even though not explicitly mentioned by the current national midterm development plan (2015-2019) developed by the National Planning Agency (BAPPENAS).

Meanwhile, realising that GHG emissions in Indonesia mostly come from peat fires and land-use change (Jupesta et al. 2011, see also Table 6), Indonesia had also become a strong proponent for REDD+. A national strategy on REDD+ was produced in 2012 and was widely considered as an example of collaborative policy making. However, it was general and since it was issued by an agency outside the bureaucracy was not considered legally binding and thus largely sidelined (Indrarto et al. 2012).

In 2014, the government changed, bringing a new agenda (Table 6). President Joko Widodo disbanded the national climate change council (DNPI) and the REDD+ agency merging them in a new ministry of Environment and Forestry. This coincided with international shifts in discourse that, in Indonesia, also led to a waning of interest in REDD+ in favor of GG. REDD+, which had been developing to improve forest governance whereby non-carbon benefits became more and more important, was thereby reduced to one tool to achieve green development and sustainable forest management objectives (Interviews \#74, 101 and 104, 2015).

The new government also made it clear that it was not willing to forego economic development. The Government of Indonesia aspires to become, and is perceived as potentially one of the top ten largest economies in the world (PWC, 2015, Nikkei Asian Review, June 25, 2015). The GG thus prioritizes a 4-track development strategy, i.e. pro-growth, pro-job, propoor, and only lastly pro-environment, to be achieved through a Low Carbon Development path (Masripatin 2010, OECD 2014, GoI and GGGI 2013).

In 2014, the Ministry of Finance through its center for climate change and multilateral finance policy (PKPPIM), issued a strategy for Green development which was updated in 2015. This strategy includes recommendations for policy change (Table 7).

The GG narrative is still unfolding. As in the early years of REDD+, numerous workshops, meetings and consultations were held to define what GG is within the context of Indonesia and BAPPENAS; to 'green' development plans; and to develop environmental standards and indicators (Interview \#74, 2015).

Meanwhile, the private sector also adopted GG with pledges for zero deforestation and commitments to forest restoration. As one respondent said: "in response to demands

TABLE 6 Government documents related to climate change and REDD+ in Indonesia

\begin{tabular}{|c|c|c|}
\hline Name of documents & Leading agency & Description \\
\hline $\begin{array}{l}\text { National Action Plan for Reducing } \\
\text { Greenhouse Gas Emissions (RAN-GRK) } \\
\text { as follow up of Presidential Regulation No } \\
61 / 2011 \text { on The National Action Plan for } \\
\text { Greenhouse Gas Emission Reduction }\end{array}$ & $\begin{array}{l}\text { Coordinating Ministry of } \\
\text { Economic Affairs }\end{array}$ & $\begin{array}{l}\text { Framework document to plan Nationally Appropriate } \\
\text { Management Activities (NAMAs). Provides the basis for } \\
\text { relevant agencies, ministries and institutions, as well as } \\
\text { regional governments (RAD-GRK) and civil society to } \\
\text { implement activities that will directly and indirectly } \\
\text { reduce the greenhouse gas (GHG) emissions. }\end{array}$ \\
\hline $\begin{array}{l}\text { National Action Plan for Climate Change } \\
\text { Adaptation (RAN-API) } 2014\end{array}$ & $\begin{array}{l}\text { Ministry of National } \\
\text { Development Planning }\end{array}$ & $\begin{array}{l}\text { Mainstreaming Adaptation into National Development } \\
\text { Planning, The plan identifies } 15 \text { vulnerable areas and } \\
\text { includes how adaptation measures can be integrated into } \\
\text { development policies, and how monitoring and evaluation } \\
\text { can be initiated. }\end{array}$ \\
\hline $\begin{array}{l}\text { Indonesia Climate Change Sectoral } \\
\text { Roadmap (ICCSR) Synthesis Report } 2010\end{array}$ & $\begin{array}{l}\text { Ministry of National } \\
\text { Development Planning }\end{array}$ & Government plan \\
\hline $\begin{array}{l}\text { Forestry Law No. } 41 / 1999 \text { (including } \\
\text { explanations on the law) }\end{array}$ & Ministry of Forestry & $\begin{array}{l}\text { General framework for the governance of forest lands in } \\
\text { Indonesia }\end{array}$ \\
\hline $\begin{array}{l}\text { Series of National Communication Under } \\
\text { The United Nations Framework } \\
\text { Convention on Climate Change } \\
\text { (UNFCCC) }\end{array}$ & Ministry of Environment & $\begin{array}{l}\text { Provides updates on Indonesia's efforts to follow the } \\
\text { UNFCC }\end{array}$ \\
\hline REDD+ National Strategy 2012 & $\begin{array}{l}\text { Indonesian REDD+ Task } \\
\text { Force }\end{array}$ & National REDD+ implementation guideline \\
\hline Indonesia INDC & $\begin{array}{l}\text { Office of the president; } \\
\text { special envoy for climate } \\
\text { change }\end{array}$ & $\begin{array}{l}\text { Outlines transition to low carbon future by describing } \\
\text { needed actions and necessary enabling factors. Includes } \\
\text { guidelines for mitigation and adaptation }\end{array}$ \\
\hline
\end{tabular}


TABLE 7 Green growth policy documents in Indonesia

\begin{tabular}{|c|c|c|}
\hline Name of document & Leading agency & Description \\
\hline $\begin{array}{l}\text { Delivering Green Growth for a } \\
\text { Prosperous Indonesia } \\
\text { A Roadmap for Policy, Planning, and } \\
\text { Investment }\end{array}$ & GoI and GGGI & $\begin{array}{l}\text { This Strategy is designed to achieve the objectives of } \\
\text { mainstreaming policy and adjusting government } \\
\text { priorities to pursue the longer-term benefits of green } \\
\text { and more sustainable development. }\end{array}$ \\
\hline $\begin{array}{l}\text { Strategy for Planning and Budgeting of } \\
\text { Green Development for Sustainable } \\
\text { Development in Indonesia 2015-2019 }\end{array}$ & $\begin{array}{l}\text { Center for climate change and } \\
\text { multilateral finance, Ministry of } \\
\text { Finance (PKPPIM) }\end{array}$ & $\begin{array}{l}\text { Outlines a green economy approach to achieving } \\
\text { SDGs in order to maintain economic growth, } \\
\text { environmental and sustainable development }\end{array}$ \\
\hline
\end{tabular}

by investors, a 'green image' emerged" (Interview \#58, 2015). Companies adopted sustainability programmes projecting an image of social and environmentally responsible enterprises. This green image has been shaped by and disseminated through the Indonesia Business Council for Sustainable Development, which was established in 2011.

In Indonesia, the way the government is structured and operates in accordance to a particular tupoksi (the terms of reference/mandate of each organization) challenges the development of a coherent policy framework. The GG policy framework, for example, is designed by the National Planning Agency (BAPPENAS), but the Coordinating Ministry for Economic Affairs and the Ministry of Finance have both independently drafted strategies for GG without attempts at consolidation. In addition, the decentralized nature of development planning and implementation allows full autonomy at district and province level. Despite good intentions, synergies and coordination both horizontally and vertically remain elusive.

\section{STAKEHOLDERS STANCES ON REDD+ AND GREEN GROWTH}

Policy actors interviewed in 2012 and 2015 in both countries pointed out that environmental degradation has continued as economic growth remains dependent on the extraction of natural resources and forest conversion for agricultural expansion. Policy makers are unlikely to change their political and financial interests in the short term and GG policies will be implemented in parallel with economic development programmes. In Vietnam, the export of rice, coffee, and rubber has become the most important source of revenue (Pham et al. 2012). The leading sectors in the economy continue to put great pressure on forest land. The policy of trade liberalization has created greater incentives for foreign and domestic companies to expand their operations inside and outside the country, including in areas related to forest products. To reduce costs and increase profits, firms seek a local input source - which often leads to deforestation (Pham et al. 2012). A similar trajectory is seen in Indonesia in the oil palm sector, where, probably under pressure from the private sector, agricultural policies on oil palm are contradictory to forestry policies to conserve forests, and energy generation is dependent on coal burning. The National Development plan remains focused on achieving economic growth and does not even mention REDD+ or GG, (RPJM I, BAPPENAS, 2014) instead focusses on sustainable (economic) development (RPJM II, Bappenans, 2014). The private sector, meanwhile, has started to adopt GG strategies such as zero-deforestation pledges and conservation/high carbon value forests as part of their sustainability plans. Rather than supporting this initiative, the government has officially rejected this commitment as it will also constrain smallholder development.

In Vietnam, key informants interviewed expressed their skepticism towards both GG and REDD+ and the difficulties in joining these two narratives. An interviewee stated, "REDD+ is already confusing and we already have had difficulties in interpreting and implementing them at provincial level and now we have to work with GG which is also very confusing."

In Indonesia there is a similar skepticism with little synergistic linkages between GG and REDD+. Both GG and REDD+ are perceived to be unclear and drifting from the original intentions of reducing deforestation and forest degradation and low carbon development (interviews \#8, 2015). In addition, the GG strategy appears to have developed in parallel to the REDD+ strategy, involving the same agencies though not necessarily the same individuals, notably BAPPENAS. BAPPENAS is in charge of drafting the national development plan (RPJMN) but, as stated earlier, this document does not mention REDD+ nor GG. GG is developed in a separate document (BAPPENAS and GGGI, 2015). Coordination between these three parallel processes (RPJMN, REDD+ and GG) is minimal even though several informants insist that REDD+ is an important component of GG (interviews \# 16, 74, 2015). Yet while doubting its implementation, Indonesian key informants tend to follow official policy (at least in a formal manner) and the BAPPENAS has clearly indicated that REDD+ is one approach under the GG strategy (interviews \#16, \#74; GoI and GGGI, 2015).

\section{DISCUSSION}

\section{Transformational changes or business as usual}

GG and REDD+ terminology have become part of the policy and planning documents in both Vietnam and Indonesia, 
characterized by a reconciliation of environmental with development objectives as a new form of transformational change. Transformational change is defined by Brockhaus et al. (2015) as "a shift in discourse, attitudes, power relations, and deliberate policy and protest action that leads policy formulation and implementation away from business as usual policy approaches that directly or indirectly support deforestation and forest degradation." However, our findings indicate that the underlying driver for this transformational change is a common interest which is rooted in national economic development. Though in Indonesia, political change played a role in re-directing priorities towards improving economic development. In both Vietnam and Indonesia, uncertainty over REDD+ global negotiations and markets have further weakened interest in REDD+ and strengthened interest in GG whereby REDD+ is seen as a tool to obtain more funding to support the national GG strategy. Moreover, GG and REDD+ are seen by government informants as a way to improve a country's position and image in the international policy arena and as a new way to tap into international funding and investment.

In Vietnam, GG is the umbrella term under which REDD+ is placed. In Indonesia, the two concepts emerged somewhat in parallel, and while linkages among them are being discussed, they are not yet formalized in a coherent policy framework. In Indonesia, however, REDD+ is considered a tool to achieve GG at a larger scale. During the preparatory phase of REDD+ in Indonesia, it was realized that REDD+ could not be achieved without some basic changes in the business as usual development. This is even more important in the larger GG frame where even more stakeholders in Indonesia are involved. In the Indonesian National Plan, the need for improving governance to realize GG is highlighted in a separate chapter (RPJM 2014-2019 book II). Yet this chapter stands alone and is not integrated in the overall picture.

Moreover, the contradiction between the rhetoric of GG, including REDD+, and the perception of conflicting objectives, and the power struggles we observed in the REDD+ policy arena between the diverse actors and their interests, indicate that there is resistance within the REDD+ policy arena and very little transformational change has been achieved. Business as usual remains firmly in place in both countries.

The dominant pathways of economic development and related macro-level indicators in both Indonesia and Vietnam do not suggest that a transition to a GE is taking shape (Jacob et al. 2013). Thus, while in both countries, the GG discourse is being mainstreamed, it remains in a rhetorical space and is not in an action arena where policy decisions are made, implemented and enforced. In Vietnam, GG remains unclear in terms of targets, measures and performance outcomes and is not related to agricultural development aimed at increasing revenue. In Indonesia, GG is promoted by BAPPENAS with support of GGGI, UNDP and others but is separated from national development plans as well as from sectoral policies.

\section{Conciling green growth and REDD+ or dilution of REDD+ agenda}

This paper highlights the mismatch between and amongst sectoral policies in both countries. For example, the policies on reducing oil consumption by partially shifting to renewable energy sources vs. the plan of establishing large coal-based power plants in Indonesia, and policies to increase forest cover vs. increase GDP through the expansion of coffee and rubber area in Vietnam (Pham et al. 2012). In the two countries studied, national strategies emphasize the role of GG and REDD+ in all sectoral policies but sectoral policies ignore both GG and REDD+. There is also a lack of ownership as REDD+ is seen in Vietnam across all interviewees as a donor project while GG is seen as being nationally driven. In both countries, policies, guidance and measures to implement both GG and REDD+ are unclear.

While we see some more policy action in the REDD+ policy arenas in Indonesia and Vietnam (Brockhaus et al. 2015), backlashes in the design and implementation of REDD+ are also numerous. With GG narratives still merely remaining at a rhetorical level and REDD+ facing strong implementation challenges, linking the two does not help progress towards a transition into a GE. In Indonesia, the disjunct between rhetoric of GG and actions focusing more on growth and less on green may set the performance standards even lower, and REDD+ policy-making will become as opaque as the definition of what is 'green' in a GE. In addition, shifting the policy discourse from REDD+ which aims to address drivers of deforestation and degradation to green growth which primarily aims to create incentives to attract domestic and foreign investment and to mobilise the private sector to participate in climate change adaptation in the case of Vietnam will further dilute the REDD+ concept and weaken policy in addressing the environmental problem. This is referred by Bluehdorn (2011) as "the politics of unsustainability and crisis".

The reconciliation of economic development with environmental protection requires innovative institutional frameworks with responsible and responsive governments in order to protect the interests of current and future generations. However, our findings lead to question the willingness to reform. Policy actors in Vietnamese and Indonesian policy arenas are not yet convinced that economic growth objectives and intentions to avoid deforestation and forest degradation can be synergetic. All interviewees in both countries take the stance that the main challenge for REDD+ implementation is to effectively address the main drivers of deforestation without compromising development objectives, reflecting the perception that REDD+ and GG for a Green Economy is more of a zero-sum struggle than a win-win possibility.

\section{CONCLUSIONS}

While GG discourses and policies have been widely articulated in both Vietnam and Indonesia in recent years, stakeholders still have vague and different interpretations of GG. 
While REDD+ seems to have a more explicit objective, namely avoiding deforestation and forest degradation, and more clarity over modalities, including commitments to performance, we found little evidence for transformational change within the two countries REDD+ policy arena. The perception of forest protection as compromising development is clearly a counter-narrative to what is promoted as an element in GG and as REDD+, namely the opportunity of realizing environmental and economic objectives. In addition, enabling conditions for both REDD+ and GG seem to be absent in the two countries. Specifically, the inability to reconcile development and environmental interests, are perceived by most actors in both countries as major barriers to implementing REDD+ and hence for changing the economic and regulatory frameworks and realizing a shift away from business as usual, central to the definitions of GG and a GE. In both countries, the state is unwilling or not capable to negotiate with and regulate in order to negotiate with powerful special interests behind the main drivers of deforestation, which suggests that there will be no transformative change.

Despite the global promotion of and the interest of the Indonesian and Vietnamese Goverments in the concepts of GG and REDD+, it seems that merging these two narratives might result into an even stronger discourse of vague, unfulfilled promises and expectations, and inaction. It can also dilute REDD+ objectives. To counteract this development, countries will need to tackle the root causes of unsustainable development, e.g. the root causes of deforestation, which will require more than just rhetoric and technical responses.

\section{ACKNOWLEDGMENTS}

The data and analysis presented here form part of the policy component of CIFOR's global comparative study on REDD+. We gratefully acknowledge the support received from the Norwegian Agency for Development Cooperation, the Australian Agency for International Development, the UK Department for International Development, the European Commission, and the Department for International Development Cooperation of Finland. We would like to thank the quest editors of this special issue Wil de Jong, Glenn Galloway, Pablo Pacheco, the three anonymous referees, and Alan Pottinger for their comments to this paper.

\section{REFERENCES}

ANDERSON, Z.R., KUSTERS, K., OBIDZINSKI, K., and MCCARTHY, J. 2015. Growing the economy: oil palm and green growth in east kalimantan, indonesia. Conference Paper No. 20. Land grabbing, conflict and agrarianenvironmental transformations: perspectives from East and Southeast Asia, 5-6 June 2015, Chiang Mai University. Chiang Mai, Thailand.

ANGELSEN, A., and MCNEIL, D. 2012. The evolution of REDD+. In: Angelsen, A., Brockhaus, M., Sunderlin,
W.D., and Verchot, L. (Eds.). Analysing REDD+: Challenges and choices. pp. 31-48. Center for International Forestry Research. Bogor, Indonesia.

BAPPENAS, 2015. Ringkasan rencana pembangunan jangka menegah nasional (RPJMN) 2015-2019. 24 January 2015. Medan, Indonesia. (in Bahasa Indonesia)

BLUEHDORN, I. 2011. The politics of unsustainability: COP 15, post-ecologism, and the ecological paradox. Organization and Environment 24(1): 34-53.

BINA, O. 2013. The green economy and sustainable development: an uneasy balance? Environment and Planning $C$ : Government and Policy 31(6): 1023-1047.

BRAND, U. 2012. Green Economy - the Next Oxymoron? No lessons learned from failures of implementing sustainable development. GAIA-Ecological Perspectives for Science and Society 21(1): 28-32.

BROCKHAUS, M., DI GREGORIO, M., and MARDIAH, S. 2014. Governing the design of national REDD+: an analysis of the power of agency. Forest Policy and Economics 49: $23-33$.

BROCKHAUS, M., KORHONEN-KURKI, K., SEHRING, J., and DI GREGORIO, M. 2015. Policy progress with $R E D D+$ and the promise of performance-based payments: A qualitative comparative analysis of 13 countries. CIFOR Working Paper 196. Center for International Forestry Research. Bogor, Indonesia.

DI GREGORIO, M., BROCKHAUS, M., CRONIN, T., MUHARROM, E., MARDIAH, S., and SANTOSO, L. 2015. Deadlock or transformational change? exploring public discourse on redd+ across seven countries. Global Environmental Politics 15(4): 63-84.

ENTMAN, R.M. 1993. Framing: Toward clarification of a fractured paradigm. Journal of Communication 43(4): $51-58$.

GGGI [GLOBAL GREEN GROWTH INSTITUTE], 2013. GGGI Indonesia: fact sheet. Green Growth Program: Mainstreaming Green Growth within Indonesia's economic planning processes. Global Green Growth Institute (GGGI). Available at: http://gggi.org/wp-content/uploads/ 2015/07/gggi_factsheet_Indonesia_Mainstreaming_ Green_Growth1.pdf

GOI [GOVERNMENT OF INDONESIA] and GGGI [GLOBAL GREEN GROWTH INSTITUTE], 2013. Government of Indonesia-GGGI Green Growth Program: prioritizing investments: delivering Green Growth. GGGI. Available at: http://www.asialeds.org/sites/default/files/ resource/file/Indonesia_Green_Growth_Program_ Oct_2013.pdf

GOV [GOVERNMENT OF VIETNAM], 2012. Decision on approval of the national action program on reduction of green-house gas emissions through efforts to reduce deforestation and forest degradation, sustainable management of forest resources, and conservation and enhancement of forest carbon stocks, 2011-2020.

GOV [GOVERNMENT OF VIETNAM], 2015. Intended Nationally Determined Contribution of Viet Nam. Submitted to the United Nations Framework Convention on Climate Change (UNFCCC) Sectariat. 
KENIS, A., LIEVENS, M. 2015. The limits of the Green Economy: From re-inventing capitalism to re-politicising the present. London, Routledge.

INDRARTO, G.B., MURHARJANTI, P., KHATARINA, J., PULUNGAN, I., IVALERINA, F., RAHMAN, J., PRANA, M.N., RESOSUDARMO, I.A.P., and MUHARROM, E. 2012. The context of REDD+ in Indonesia: drivers, agents, and institutions. Center for International Forestry Research. Bogor, Indonesia. Available at: http://www. cifor.org/online-library/browse/view-publication/publication/ 3876.html

JACOBS, M. 2013. Green growth. In: Falkner, R., (Ed.) Handbook of Global Climate and Environmental Policy. Wiley-Blackwell. Oxford, UK.

JACOB, K., KAUPPERT, P., and QUITZOW, R. 2013. Green growth strategies in Asia: drivers and political entry points. Friedrich Ebert Stiftung. Bonn, Germany. Available at: http://library.fes.de/pdf-files/iez/10403.pdf

JOUVET, P.J., and DE PERTHUIS, C., 2013. Green Growth: From intention to implementation. International Economics. Available online 26 June 2013.

JUPESTA, J., BOER, R., PARAYIL, G., HARAYAMA, Y., YARIME, M., PUPPIM DE OLIVEIRA, J.A., and SUBRAMANIAN, S.M. 2011. Managing the transition to sustainability in an emerging economy: evaluating green growth policies in Indonesia. Environmental Innovation and Societal Transitions 1: 187-191.

KORHONEN-KURKI, K., SEHRING, J., BROCKHAUS, M., and DI GREGORIO, M. 2014. Enabling factors for establishing REDD plus in a context of weak governance. Climate Policy (2): 167-186. http://dx.doi.org/10.1080/14 693062.2014.852022

MOELIONO, M., GALlEMORE, C., SANTOSO, L., BROCKHAUS, M., and DI GREGORIO, M. 2014. Information networks and power: confronting the 'wicked problem' of REDD+ in Indonesia. Ecology and Society 19(2): 9. http://dx.doi.org/10.5751/ES-06300-190209

MONGABAY, 2013. Catatan Akhir Tahun: Komitmen Pengurangan Laju Emisi Pemerintah Indonesia Diragukan Bakal Tercapai (End of year notes: it is doubtful that the Government commitment on reducing emissions can be achieved). 28 December 2013. Available at: http://www. mongabay.co.id/tag/mp3ei/ (in Bahasa Indonesia)

OECD [THE ORGANISATION FOR ECONOMIC COOPERATION AND DEVELOPMENT], 2012. Green growth and developing countries: a summary for policy makers. June 2012.

OECD [THE ORGANISATION FOR ECONOMIC COOPERATION AND DEVELOPMENT], 2014. Green Growth Indicators 2014. OECD Green Growth studies. OECD Publishing. Available at: http://dx.doi.org/10.1787/ 9789264202030-en

PHAM, T.T., MOELIONO, M., NGUYEN, T.H., NGUYEN, H.T., and VU, T.H. 2012. The context of REDD+ in Vietnam: drivers, agents and institutions. Occasional Paper 75. Center for International Forestry Research. Bogor, Indonesia.

PHAM, T.T., DI GREGORIO, M., CARMENTA, R., BROCKHAUS, M., and LE, N.D. 2014. The REDD+ policy arena in Vietnam: participation of policy actors. Ecology and Society 19(2): 22. http://dx.doi.org/10.5751/ ES-06389-190222

SAMANS, R. 2013. Green Growth and the post-2015 development agenda. An Issue Paper for the United Nations High Level Panel of Eminent Persons. Global Green Growth Institute (GGGI). Available at: http://gggi.org/ green-growth-and-the-post-2015-development-agendaby-richard-samans/

SCHULZ, C., and BAILEY, I. 2014. The green economy and post-growth regimes: opportunities and challenges for economic geography. Geografiska Annaler: Series B, Human Geography 96: 277-291. doi: 10.1111/geob. 12051

SCOTT, A., MCFARLAND, W., and SETH, P. 2013. Research and evidence on Green Growth. Overseas Development Institute for Evidence on Demand. Available at: http://r4d.dfid.gov.uk/pdf/outputs/EoD/EoD_ HD064_July2013_GreenGrowth_Final.pdf

ELIZABETH, A., SHANAHAN, MICHAEL, D. JONES, and MARK, K. 2011. McBeth Policy Narratives and Policy Processes. The Policy Studies Journal 39(3): 535-562.

SLUNGE, D., EKBOM, A., FERNANDO LOAYZA, F., GUTHIGA, P., and NYANGENA, W. 2011. Can Strategic Environmental and Social Assessment of REDD+ Improve Forest Governance? Working Papers in Economics No. 493, University of Gothenburg. Sweden.

UN [ UNITED NATIONS] and ADB [ASIAN DEVELOPMENT BANK], 2012. Green growth, resources and resilience: environmental sustainability in Asia and the Pacific. United Nations and Asian Development Bank publication ST/ESCAP/2600, RPT124260.

UNEP [UNITED NATIONS ENVIRONMENT PROGRAMME], 2011, Towards a Green Economy: Pathways to Sustainable Development and Poverty Eradication A Synthesis for Policy Makers. http://www.unep.org/ greeneconomy

UNEP [UNITED NATIONS ENVIRONMENT PROGRAMME], 2014. Building natural capital: how REDD+ can support a green economy. Report of the International Resource Panel, United Nations Environment Programme. Nairobi, Kenya.

UN-REDD, 2014. REDD+ and a green economy: opportunities for a mutually supportive relationship. UN-REDD Programme Policy Brief 01.

VNFOREST [VIETNAM ADMINISTRATION OF FORESTRY], 2013. Linking REDD+ and the National Green Growth Strategy. Presentation of VNForest with Input from the MPI/UNDP SD and CP Project. Available at: http://www.unorcid.org/upload/doc_lib/20130624182021_ 2.\%20Mr.\%20Tat\%20Do\%20Troung_Linking\% 20 REDD $\% 20$ and $\% 20$ the $\% 20$ National $\% 20$ Green $\% 20$ Growth\%20Strategy.pdf

WATSON, C., BRICKELL, E., MCFARLAND, D., and MCNEELY, J. 2013. Integrating REDD+ into a green economy transition: opportunities and challenges. Overseas ODI Report June 2013.

WORLD BANK, 2012. Inclusive Green Growth: The pathway to sustainable development. http://elibrary. worldbank.org/doi/book/10.1596/978-0-8213-9551-6 